\title{
Digestive disorders induced by the accumulation of arsenic in the human body
}

\section{Tulburările digestive induse de acumularea arseniului în organismul uman}

\author{
Alina EPURE ${ }^{1}$, Dan Mircea CHEȚA ${ }^{1,2}$ \\ ${ }^{1}$ Universitatea de Medicină și Famacie „Carol Davila“, București, România \\ ${ }^{2}$ Institutul Național de Diabet Zaharat, Nutriție și Boli Metabolice „N.C. Paulescu“, București, România
}

\begin{abstract}
Exposure to arsenic is common, but unconscious, inducing major imbalances especially in the digestive tract, lungs, skin. Contamination is achieved by exposure to arsenic in the air, soil, groundwater, food. It is noted the use of arsenic in pesticides, herbicides, paints, wood preservatives, drinking water, various foods with a wide range of consumption (seafood, rice - including rice milk, rice bran, rice cereals, rice syrup rice, rice crackers).

The diagnosis of arsenic poisoning is an important step in establishing the diet and detoxification treatment, focusing on the cause, not the symptoms. We present the case of a 45-year-old patient with symptoms manifested in the digestive tract for 4 years: abdominal bloating, cramps, vomiting, weekly episodes of acute diarrhea.

During these period the patient received multiple treatments depending on the symptoms, without a significant improvement, without performing specific investigations of arsenic poisoning. The personalized diet and treatment plan, used in the case of this patient, for a period of 4 months was distinguished by a total solution of the manifestations presented in the anamnesis stage.
\end{abstract}

Keywords: digestive disorders, arsenic toxicity, personalized diet plan, arsenic detoxification

\section{REZUMAT}

Expunerea la arseniu este frecventă, dar neconștientizată, inducând dezechilibre majore în special la nivelul tubului digestiv, plămânilor, pielii. Contaminarea se realizează prin expunerea la arseniul din aer, sol, pânza freatică, alimente. Se remarcă utilizarea arseniului în pesticide, ierbicide, vopsele, conservanți pentru lemn, apă potabilă, diferite alimente cu un spectru larg de consum (fructe de mare, orez-inclusiv lapte de orez, tărâțe de orez, cereale pe bază de orez, sirop de orez, crackers de orez).

Diagnosticarea intoxicațiilor cu arseniu reprezintă un pas important $\hat{\imath}$ stabilirea planului alimentar și a tratamentului de detoxifiere, cu accent pe cauză, nu pe simptomatologie. Vă prezentăm cazul unei paciente $\hat{\imath} n$ vârstă de 45 ani, cu simptome manifestate la nivelul tubului digestiv de 4 ani: meteorism abdominal, crampe, stări de vomă, episoade săptămânale de diaree acută.

In această perioadă, pacienta a administrat multiple tratamente în funcție de simptome, fără o îmbunătățire semnificativă, fără efectuarea investigațiilor specifice intoxicației cu arseniu. Planul personalizat de alimentație și de tratament, utilizat in cazul acestei paciente pentru o perioadă de 4 luni, s-a remarcat printr-o soluționare totală a manifestărilor prezentate în etapa de anamneză.

Cuvinte cheie: tulburări digestive, intoxicație cu arseniu, plan de alimentație personalizat, detoxifiere de arseniu 


\section{INTRODUCERE}

În literatura de specialitate, se cunoaște impactul avut de intoxicațiile cu metale grele, în special cu arseniu, fiind prezentate diferite surse de contaminare și dezechilibrele induse organismului uman, afectând starea noastră de sănătate (1). Acesta este clasificat în categoria xenobioticelor, substanțe chimice fără valoare pentru organismul viu, dar cu efecte distructive asupra acestuia.

Atât arseniul organic, cât și cel anorganic reprezintă o sursă de intoxicare, dar forma anorganică, regăsită în special în pânza freatică, perturbă procesele enzimatice (2).

Arseniul din aer, sol, pânza freatică, alimente, pesticide, ierbicide, vopsele, conservanți pentru lemn, apă potabilă, diferite alimente cu un spectru larg de consum - fructe de mare, orez (3) (inclusiv lapte de orez, tărâțe de orez, cereale pe bază de orez, sirop de orez, crackers de orez).

Prezența arseniului induce o acumulare de radicali liberi, implicit stresul oxidativ ce poate genera leziuni la nivel de ADN (4), afectarea, transmiterea și reglarea intracelulară.

Simptomele asociate intoxicației cu arseniu sunt prezente la nivel de creier, inimă, piele și funcționarea celulară. Expunerea acută poate induce dezechilibre mentale, stări de oboseală, dureri de cap, crampe abdominale, stări de vomă, diaree acută, anemie. Expunerea cronică se reflectă prin neuropatie periferică, diabet (5), boli cardiace (6), keratoză, disfuncționalitate hepatică, cancer de prostată, ficat, rinichi, piele, plămâni (7).

\section{SCOPUL LUCRĂRII}

Prin prezentarea acestui caz se dorește evidențierea importanței implementării unui plan integrat de tratament, din cadrul căruia programul personalizat de alimentație are un rol esențial. Terapia de detoxifiere pentru arseniu s-a realizat sub atenta monitorizare a pacientei de către echipa interdisciplinară, astfel încât să fie adaptată în funcție de simptomele manifestate de pacientă.

S-a obținut consimțământul de informare a pacientei de a prezenta acest caz.

\section{PREZENTAREA CAZULUI}

Prezentăm cazul unei paciente în vârstă de 45 ani, cu o greutate de $52 \mathrm{~kg}$, circumferința abdominală de 78 cm, ce manifestă în mod constant meteorism abdominal, asociat cu stări de vomă, crampe, episoade săptămânale de diaree acută.

În etapa de anamneză a pacientei s-a precizat că aceste manifestări sunt prezente de 4 ani, în această perioadă administrând diferite tratamente pentru fiecare simptomatologie în parte, fără să observe o îmbunătățire semnificativă, nefiind susținute de un plan de alimentație adaptat simptomelor exprimate.
În aceste condiții, s-a recurs la investigații suplimentare în vederea stabilirii unui diagnostic. Ca urmare a interpretării rezultatelor obținute, s-a confirmat intoxicația cu arseniu 14,43 mg/l, cu interval de referință 0,00-2,30 mg/l.

Metoda de lucru folosită în analizarea arseniului a fost AAS, spectrometria de absorbție atomică UV, cu specificitate înaltă.

După ce s-a realizat o evaluare detaliată a stilului de viață avut de pacientă în ultimii 4 ani, echipa interdisciplinară ce a studiat acest caz a ajuns la concluzia că alimentația era dezechilibrată, fiind introduse, în medie, 5 porții de orez în meniul săptămânal, alături de 5 porții de pește de culoare închisă și 5 beri.

$\mathrm{Ca}$ atitudine terapeutică, s-a inițiat un protocol de tratament de detoxifiere și un plan personalizat de alimentație, pentru o perioadă de 120 de zile, evoluția pacientei fiind un factor decisiv în adaptarea continuă a planului stabilit inițial. S-au administrat următoarele: supliment omega 3 , cu o concentrație crescută de DHA - 0,15 ml/kg greutate corporală/ zi, seleniu $(200 \mathrm{mcg} / \mathrm{zi})$, probiotic (1 capsulă x 3/zi), spirulină (250 $\mathrm{mg} / \mathrm{zi}$ ), zinc ( $60 \mathrm{mg} / \mathrm{zi})$, glutation $600 \mathrm{mg} / 4 \mathrm{ml}$ (3 tratamente/săptămână). Expunerea la saună cu infraroșu s-a realizat de 3 ori în fiecare săptămână.

Din punct de vedere alimentar, s-au adoptat următoarele schimbări: eliminarea alimentelor cu potențial ridicat de intoxicare cu arseniu (pește de culoare închisă, bere, orez), realizarea unei selecții în ceea ce privește calitatea alimentelor, fiind consumate numai fructele și legumele ecologice, eliminând astfel o posibilă contaminare a fructelor și legumelor cu pesticide ce conțin arseniu. În planul zilnic de alimentație au fost introduse alimentele $\mathrm{cu}$ un conținut ridicat de antioxidanți: 5 nuci braziliene, $100 \mathrm{ml}$ suc de afine sau mure. S-au stabilit reguli de asociere corectă a alimentelor, și anume: 3 mese principale în fiecare zi, la ore fixe; evitarea asocierii a 2 tipuri de proteină animală la aceeași masă (de exemplu carne și ou); evitarea hidratării cu 30 minute înainte de mesele principale, în timpul meselor și la 30 minute după mesele principale; introducerea în meniul zilnic a fructelor și legumelor de culori diferite, în stare crudă (portocaliu, verde, roșu).

Hidratarea s-a efectuat cu apă alcalină, a cărei analiză a fost efectuată și nu prezenta risc de contaminare cu arseniu.

După prima săptămână de adaptare la noul profil alimentar și la schema de tratamente, s-a redus semnificativ numărul de episoade cu diaree acută, nu s-a manifestat niciun episod cu stări de vomă, meteorismul abdominal și crampele au fost reduse de la 10 la 7 (pe o scară de evaluare individuală, cu un maximum de 10).

La finalul primelor 2 săptămâni în care s-a implementat un plan personalizat și integrat de alimentație și tratamente, s-a observat o reducere a meteorismului abdominal și a crampelor, care erau manifestate pe toată durata zilei în etapa de anamneză de la 7 la 5.

După primele 2 luni, starea generală era semnificativ îmbunătățită și circumferința abdominală redusă de la 78 
la $72 \mathrm{~cm}$, ceea ce reflecta o normalizare a tranzitului intestinal, cu reducerea meteorismului abdominal de la 5 la 2.

La analizele efectuate la finalul celor 4 luni, s-a observat că arseniul a înregistrat valori situate în intervalul de referință, iar pacienta nu mai prezenta niciunul dintre simptomele manifestate inițial, circumferința abdominală fiind de $67 \mathrm{~cm}$.

După aceste 4 luni, pacienta a menținut regulile de bază ale unui stil de viață echilibrat, fără să mai introducă pește colorat, orez, bere în planul de alimentație. S-a continuat administrarea probioticelor, în 2 reprize anuale, de câte 3 luni fiecare.

Monitorizarea pacientei s-a realizat prin repetarea analizelor de sânge specifice pentru arseniu, la interval de 6 luni, nefiind înregistrată o nouă creștere a nivelului de arseniu din sânge. Tulburările digestive nu au mai fost evidențiate în următorii 2 ani de la finalizarea schemei de tratament.

\section{DISCUŢII}

Tulburările digestive se tratează punctual, în funcție de simptomele manifestate, și se recurge în mod frecvent la introducerea orezului în planul de alimentație, atât timp cât sunt prezente episoade de diaree acută, crampe abdominale, meteorism abdominal, fără să se realizeze o evaluare completă, care să includă și analiza pentru arseniu.

Arseniul este unul dintre cele mai toxice metale, fiind prezent în apă, aer, sol (8), sub 2 forme (organic și anorganic), dar efectele adverse ale expunerii cronice la arseniu nu sunt foarte bine documentate.

În afară de tubul digestiv, arseniul își poate face simțită prezența în tot corpul, inducând dezechilibre majore, manifestate în funcție de metabolismul individual, de rezervele de antioxidanți.

Chiocchetti și colaboratorii au prezentat cazul unei expuneri cronice la arseniu anorganic As (III) a epiteliului intestinal, timp de 6 luni. În această perioadă, celulele NCM460, celule epiteliale netransformate din colonul uman, au fost expuse la As (III) și monitorizate

\section{REFERENCES}

1. Rehman MU, Khan R, Khan A, Qamar W, Arafah A, Ahmad A, Ahmad A, Akhter R, Rinklebe J, Ahmad P. Fate of arsenic in living systems: Implications for sustainable and safe food chains. J Hazard Mater. 2021 Sep 5;417:126050.

2. Coleman $\mathrm{N}$, Castrejon $\mathrm{A}$, Blaine $\mathrm{C}$, Chemmachel T. The Toxicology of Essential and Nonessential Metals. Lulu Publishing Services, 2017

3. Mawia AM, Hui S, Zhou L, Li H, Tabassum J Lai C, Wang J, Shao G, Wei X, Tang S, Luo J, Hu S, Hu P. Inorganic arsenic toxicity and alleviation strategies in rice. J Hazard Mater. 2021 Apr 15;408:124751.

4. Hughes MF. Arsenic toxicity and potential mechanisms of action. Toxicol Lett. $2002 \mathrm{Jul}$ 7;133(1):1-16.

pentru achiziționarea unui fenotip asemănător tumorii. S-a evidențiat că astfel este facilitată achiziționarea caracteristicilor celulelor transformate (9).

Milioane de oameni din India, Taiwan, Chile, Bangladesh consumă zilnic apă contaminată cu arseniu și sunt semnalate în mod frecvent cazuri de intoxicații cu arseniu. Misbahuddin și colaboratorii au prezentat un studiu realizat pe un lot de 41 pacienți, cărora li s-a administrat un tratament placebo (la 17 pacienți), respectiv un tratament cu spirulină (250 mg), zinc (2 mg), administrat de 2 ori în fiecare zi, la 24 pacienți, timp de 16 săptămâni. La finalul acestei perioade, s-a evidențiat reducerea efectelor arseniului asupra organismului la lotul de 24 de pacienți, cărora li s-a administrat zilnic tratamentul cu spirulină și zinc (10).

Yuan și colaboratorii au prezentat un studiu efectuat pe 11 pacienți, internați cu otrăvire subacută cu arseniu din apa potabilă contaminată cu arseniu. Principalele manifestări au fost gastroenterită, afectarea pielii, ficatului, rinichilor, urmată de afectarea sistemului nervos periferic. Tratamentul a ajutat, dar recuperarea neuropatiei periferice cronice severe a fost tardivă (11).

Particularitatea cazului prezentat constă în diagnosticarea intoxicației cu arseniu, asocierea planului de alimentație cu protocolul de tratament, personalizându-se această schemă în funcție de evoluție de către o echipă interdisciplinară de specialiști.

\section{CONCLUZII}

Simptomatologia asociată prezenței arseniului trebuie avută în vedere în etapa de diagnosticare până la stabilirea unei scheme de tratament și trebuie încurajat fiecare pacient să urmeze un program de alimentație personalizat, astfel încât să obțină rezultate în timpul procedurii de detoxifiere.

Admistrarea unui plan de tratament, fără a fi asociat cu un program de alimentație, poate reduce în mod semnificativ eficiența tratamentelor, existând posibilitatea unei expuneri zilnice la o sursă de recontaminare.

Conflict of interest: none declared Financial support: none declared

5. Eick SM, Steinmaus C. Arsenic and Obesity: a Review of Causation and Interaction. Curr Environ Health Rep. 2020 Sep;7(3):343-351.

6. Karagas MR, Punshon T, Davis M, Bulka $\mathrm{CM}$, et al. Rice Intake and Emerging Concerns on Arsenic in Rice: a Review of the Human Evidence and Methodologic Challenges. Curr Environ Health Rep. 2019 Dec;6(4):361-372.

7. Naujokas MF, Anderson B, Ahsan H, Aposhian HV, Graziano JH, Thompson C, Suk WA. The broad scope of health effects from chronic arsenic exposure: update on a worldwide public health problem. Environ Health Perspect. 2013 Mar;121(3):295-302.

8. Balali-Mood M, Naseri K, Tahergorabi Z, Khazdair MR, Sadeghi M. Toxic Mechanisms of Five Heavy Metals: Mercury, Lead,
Chromium, Cadmium, and Arsenic. Front Pharmacol. 2021 Apr 13;12:643972.

9. Chiocchetti GM, Vélez D, Devesa V. Effect of chronic exposure to inorganic arsenic on intestinal cells. J Appl Toxicol. 2019 Jun;39(6):899-907.

10. Misbahuddin M, Islam AZ, Khandker S, Ifthaker-Al-Mahmud, Islam N, Anjumanara. Efficacy of spirulina extract plus zinc in patients of chronic arsenic poisoning: a randomized placebo-controlled study. Clin Toxicol (Phila). 2006;44(2):135-41.

11. Yuan J, Lai Y, Huang CT, Huang L, Tang FK, Hong L, Yang YM. Clinical analysis of 11 cases of sub-acute arsenic poisoning. Zhonghua Lao Dong Wei Sheng Zhi Ye Bing Za Zhi. 2020 Dec 20;38(12):921-924. 